\title{
Impact of Variants Within Seven Candidate Genes on Statin Treatment Efficacy
}

\author{
M. VRABLÍK ${ }^{1 *}$, J. A. HUBÁČEK ${ }^{2 *}$, D. DLOUHÁ ${ }^{2}$, V. LÁNSKÁ ${ }^{2}$, J. RYNEKROVÁ $^{2}$, \\ L. ZLATOHLÁVEK ${ }^{1}$, M. PRUSÍKOVÁ ${ }^{1}$, R. ČEŠKA ${ }^{1}$, V. ADÁMKOVÁ ${ }^{2}$ \\ *These authors contributed equally.
}

${ }^{1}$ Third Department of Internal Medicine, First Faculty of Medicine, Charles University and General University Hospital in Prague, Prague, Czech Republic, ${ }^{2}$ Institute for Clinical and Experimental Medicine, Prague, Czech Republic

Received February 19, 2012

Accepted June 11, 2012

On-line October 25, 2012

\section{Summary}

Statins are the most commonly used drugs in patients with dyslipidemia. Among the patients, a significant inter-individual variability with supposed strong genetic background in statin treatment efficacy has been observed. Genome wide screenings detected variants within the CELSR2/PSRC1/SORT1, CILP2/PBX4, $A P O B, A P O E / C 1 / C 4, H M G C O A$ reductase, $L D L$ receptor and $P C S K O$ genes that are among the candidates potentially modifying response to statins. Ten variants (SNPs) within these genes (rs599838, rs646776, rs16996148, rs693, rs515135, rs4420638, rs12654264, rs6511720, rs6235, rs11206510) were analyzed in 895 (46\% men, average age $60.3 \pm 13.1$ years) patients with dyslipidemia treated with equipotent doses of statins ( $~ 90 \%$ on simvastatin or atorvastatin, doses 10 or $20 \mathrm{mg}$ ) and selected 672 normolipidemic controls (40\% men, average age 46.5 years). Lipid parameters were available prior to the treatment and after 12 weeks of therapy. Statin treatment resulted in a significant decrease of both total cholesterol $(7.00 \pm 1.53 \rightarrow 5.15 \pm 1.17$ $\mathrm{mmol} / \mathrm{l}, \quad \mathrm{P}<0.0001)$ and triglycerides $(2.03 \pm 1.01 \rightarrow 1.65 \pm 1.23$ $\mathrm{mmol} / \mathrm{l}, \mathrm{P}<0.0005)$. Rs599838 variant was not detected in first analyzed 284 patients. After adjustment for multiple testing, there was no significant association between individual SNPs and statin treatment efficacy. Only the rs4420638 (APOE/C1/C4 gene cluster) $\mathrm{G}$ allele carriers seem to show more profitable change of HDL cholesterol ( $P=0.007$ without and $P=0.06$ after adjustment). Results demonstrated that, although associated with plasma TC and LDL cholesterol per se, variants within the CELSR2/PSRC1/SORT1, CILP2/PBX4, APOB, APOE/C1/C4, HMGCOA reductase, $L D L$ receptor and PCSK genes do not modify therapeutic response to statins.

\author{
Key words \\ Statins • Efficacy • Genes • Polymorphisms
}

\section{Corresponding author}

M. Vrablík, Third Department of Internal Medicine, General University Hospital, U Nemocnice 1, 12808 Prague 2, Czech Republic. Fax: +420 224966 677. E-mail: michal.vrablik@vfn.cz

\section{Introduction}

Inhibitors of hydroxy-methylglutaryl coenzyme A reductase (statins) are the most commonly prescribed drugs in cardiovascular prevention both in primary and secondary prevention. Not only ameliorating plasma atherogenic lipoprotein profile, but also possessing a plenty of other pleiotropic effects (for example see Pitha et al. 2010) these agents reduce the risk of both cardioand cerebro- vascular events in a wide spectrum of patients (Sadowitz et al. 2010).

However, plasma cholesterol lowering effect of statins significantly differs among individuals - namely, the use of the same dose of the same statin in different patients produces LDL-cholesterol decrease in a wide range from 8 to $55 \%$, and a reduction of triglyceride (TG) concentrations from 7 to $30 \%$ (Sever et al. 2003). Importantly, also the time to reach maximum decrease differs significantly between individuals (Hachem and Mooradian 2006). The individual response to statins is relative stable over time and, likely, has a genetic background. 
Table 1. Basic characteristics of the analyzed groups.

\begin{tabular}{|c|c|c|c|c|}
\hline Character & \multicolumn{2}{|c|}{ Patients } & Controls & $\mathbf{P}$ \\
\hline Number & \multicolumn{2}{|c|}{895} & 672 & \\
\hline Age & \multicolumn{2}{|c|}{$60.3 \pm 13.1$} & $42.5 \pm 10.2$ & \\
\hline \multirow[t]{2}{*}{$\%$ of males } & \multicolumn{2}{|c|}{46} & 40 & \\
\hline & Before & After & & \\
\hline Total cholesterol & $7.00 \pm 1.53$ & $5.15 \pm 1.17$ & $4.35 \pm 0.42$ & 0.0001 \\
\hline HDL cholesterol & $1.43 \pm 0.48$ & $1.41 \pm 0.40$ & $1.38 \pm 0.35$ & 0.08 \\
\hline Triglycerides & $2.03 \pm 1.01$ & $1.65 \pm 1.23$ & $1.03 \pm 0.37$ & 0.0001 \\
\hline
\end{tabular}

$\mathrm{P}$ is given for the differences before and after treatment in the patients group.

So far, no single mutation was described leading to the inefficient statin treatment and it was proved that the genetic determination of statin treatment efficacy is based on polygenic background (Mangravite and Krauss, 2007, Maggo et al. 2011). Dozens of individual variants were tested in effort to detect significant genetic determinants of statin treatment efficacy, however the results are so far inconsistent and far from the potential clinical use. Results of genome wide association studies (Kathiresan et al. 2008, Sandhu et al. 2008) have pointed on several gene regions that significantly influence plasma cholesterol levels per se.

These new genes or newly detected variants within the well known and characterized genes include CELSR2/PSRC1/SORT1 (rs646776 and rs599838), CILP2/PBX4 (rs16996148), APOB (rs693 and rs515135), $A P O E / C 1 / C 4$ gene cluster (rs4420638), HMGCoA reductase (rs12654264), LDL receptor (rs6511720) and PCSK9 (rs11206510 and rs6235).

To evaluate the potential role of gene variants within these newly identified gene regions in the modification of individual treatment response to statins (modulation of the final impact of statin treatment on lipoprotein levels in the plasma) we conducted a retrospective study in a cohort of lipid clinic patients treated with statins.

\section{Methods}

\section{Patient selection}

Patients with primary dyslipidemia indicated for statin treatment were selected at i/ Lipid Clinics of the Third Department of Internal Medicine of the First Faculty of Medicine, Charles University and ii/ at the Institute for Clinical and Experimental Medicine, Prague,
Czech Republic.

Eight hundred ninety five adult patients were included, average age $60.3 \pm 13.1$ years (411 males, aged $60.8 \pm 12.8$ years and 484 females, aged $59.7 \pm 13.5$ years). All patients received a standardized lifestyle advice at their first visit to the clinics and were instructed to maintain low-cholesterol/low fat diet according to the standardized education provided by an experienced dietitian. Table 1 shows the baseline characteristics of the study group. We compared the pre-treatment lipid levels with the first values obtained after initiation of statin treatment, usually after 12 weeks (range 10 to 13 weeks) of therapy. Patients taking simvastatin (32\%), atorvastatin $(47 \%)$ and rosuvastatin $(21 \%)$ in doses of 10 or $20 \mathrm{mg} /$ day were enrolled in the study. The treatment effects were evaluated after adjusting for differential potency of individual molecules and for the dose. We did not include subjects on combination lipidlowering therapy (e.g. statin-fibrate, statin-ezetimibe) and those who experienced weight loss of more than $5 \%$ between visits suggesting a substantial impact of lifestyle changes. Also, the individuals fulfilling the clinical and laboratory criteria of familial hypercholesterolemia were not included in the study.

\section{Controls selection}

A subset of 672 healthy individuals (282 males and 390 females) selected from the Central European Czech post-MONICA study $(2,559$ individuals of Caucasian ethnicity, 1,191 males, average age 49.0 \pm 10.7 years) was used (Thunsdall-Pedoe et al. 2003). The criteria for the selection were i) no history of (self reported) cardiovascular disease, ii) no lipid-lowering treatment (self reported) and iii) the plasma lipid values below $5.2 \mathrm{mmol} / \mathrm{l}$ for total cholesterol, below $2.0 \mathrm{mmol} / \mathrm{l}$ 
Table 2. Primer sequences, restriction enzymes and size of the restriction fragments used for detection of polymorphisms of interest.

\begin{tabular}{|c|c|c|c|c|c|c|}
\hline Polymorphism & Primer sequence & $\begin{array}{c}\text { Annealing } \\
\text { temperature }\end{array}$ & $\begin{array}{c}\text { PCR } \\
\text { product }\end{array}$ & Enzyme & $\begin{array}{l}\text { Size } \\
\text { (bp) }\end{array}$ & Allele \\
\hline$C I L P 2 / \ldots$ & 5, tgg ctc ttg tcc act ggc cac atc ccc & $70{ }^{\circ} \mathrm{C}$ & $135 \mathrm{bp}$ & Hin1II & 137 & $\mathrm{G}$ \\
\hline$r s 16996148$ & $5^{\prime}$ ttc tcc cat gec tcc agg cec cca ag & & & & $82+54$ & $\mathrm{~T}$ \\
\hline Apo B & 5'aga gga aac caa ggc cac agt tgc & $57.5^{\circ} \mathrm{C}$ & $163 \mathrm{bp}$ & XhoI & 136 & $\mathrm{C}$ \\
\hline$r s 693$ & 5 , tac att cgg tct cgt gta tct tct & & & & $110+26$ & $\mathrm{~T}$ \\
\hline Apo B & 5'cct agt taa tcc tca gaa tga cac tg & $59^{\circ} \mathrm{C}$ & 369 bp & BglII & 369 & G \\
\hline rs515135 & 5' att ggg gtg gca ata ggc gca aat tg & & & & $261+108$ & A \\
\hline CELSR2/... & $5^{\prime}$ atc cag cta ttt ggg agc agt gtc ctg g & $66^{\circ} \mathrm{C}$ & $137 \mathrm{bp}$ & Hin1II & 139 & A \\
\hline$r s 646776$ & 5'aag gtc tgg tct ctg gaa aac aga ag & & & & $107+32$ & $\mathrm{G}$ \\
\hline PCSK9 & 5 ' ccc agc att gec agc ttc tct gtc tc & $68.9^{\circ} \mathrm{C}$ & $130 \mathrm{bp}$ & Hin6I & 130 & $\mathrm{~T}$ \\
\hline rs11206510 & 5' agc caa aga cgg cca cca cag aca gc & & & & $104+26$ & $\mathrm{C}$ \\
\hline PCSK9 & 5' atg agt tgg agg agg gag ccc ctt cc & $57.5^{\circ} \mathrm{C}$ & $133 \mathrm{bp}$ & PstI & 133 & $\mathrm{G}$ \\
\hline$r s 6235$ & 5'aag ttt tca taa ggg atg ttg agc tct gc & & & & $103+30$ & $\mathrm{C}$ \\
\hline$H M G-C o A r$ & $5^{\prime}$ atg tet cec cet ctc cag gtg ttc ac & $56.5^{\circ} \mathrm{C}$ & $138 \mathrm{bp}$ & Hin1II & 138 & $\mathrm{~T}$ \\
\hline$r s 12654264$ & 5 , cca tha aaa atg cac agt ctc tat atc $t$ & & & & $110+28$ & A \\
\hline$L D L$-receptor & 5 , acc ggg gat gat gat gat tgc & $62{ }^{\circ} \mathrm{C}$ & $132 \mathrm{bp}$ & DpnI & 132 & $\mathrm{G}$ \\
\hline rs6511720 & $5^{\prime}$ ttg cet aag act tca tta aca ttt $g$ & & & & $106+26$ & $\mathrm{~T}$ \\
\hline $\mathrm{APOE} / \mathrm{Cl} / \mathrm{C} 4$ & $5^{\prime}$ tta act cca tgg tct caa aag agt ctt cc & $59.2{ }^{\circ} \mathrm{C}$ & $340 \mathrm{bp}$ & Mae I & 340 & G \\
\hline$r s 4420638$ & 5 ' tga ggc agg ata atc tct tga acc tgg g & & & & $185+155$ & A \\
\hline
\end{tabular}

for plasma $\mathrm{TG}$ and over $0.7 \mathrm{mmol} / 1$ (for males) or $0.8 \mathrm{mmol} / \mathrm{l}$ (for females) for HDL-cholesterol (Table 1).

Written informed consent was obtained from all the study participants and the local ethics committee approved the design of the study according to the Declaration of Helsinki of 2000.

\section{Genotype analysis}

Three millilitres of whole blood collected into EDTA tubes for DNA isolation were stored at $-20{ }^{\circ} \mathrm{C}$. The DNA was isolated using the standard salting out method (Miller et al. 1988) and individual variants within the seven genes (rs646776 and rs599838 CELSR2/PSRC1/SORT1, rs16996148 - CILP2/PBX4, rs693 and rs515135 - $A P O B$, rs4420638 - APOE/C1/C4 gene cluster, rs12654264 - HMGCoA reductase, rs11206510 and rs6235 - PCSK9 and rs6511720 - LDL receptor) were genotyped using polymerase chain reaction (PCR) and restriction analysis. A PCR device DYAD (MJ Research, Waltham, MA) was used to perform the PCR reaction in a total volume of $25 \mu \mathrm{l}$. DNA was amplified under the following conditions: initial denaturation of $96^{\circ} \mathrm{C}$ for $3 \mathrm{~min}$, followed by 35 cycles of $95^{\circ} \mathrm{C}$ for $15 \mathrm{~s}$, appropriate annealing temperature for $30 \mathrm{~s}$ and $72{ }^{\circ} \mathrm{C}$ for $30 \mathrm{~s}$ with the last amplification step was extended for $3 \mathrm{~min}$ at $72{ }^{\circ} \mathrm{C}$.
A ten $\mu$ of PCR product was digested in a total volume of $25 \mu \mathrm{l}$ with an appropriate restriction enzyme at $37^{\circ} \mathrm{C}$ overnight in the buffer provided by the manufacturer (Fermentas, Burlington, Canada). For more details regarding the PCR conditions, oligonucleotides and restriction enzymes used, see Table 2. Restriction fragments were separated on $10 \%$ PAA gel using the high capacity MADGE technique (Day and Humphries 1994).

\section{Analysis of plasma lipids}

The lipoprotein parameters in fasting plasma samples were assessed using autoanalyzers and conventional enzymatic methods with reagents from Boehringer Mannheim Diagnostics and Hoffmann-La Roche in CDC Atlanta accredited local laboratories.

\section{Statistical analysis}

The Hardy-Weinberg test (http://www.tufts.edu/ $\sim$ mcourt01/Documents/Court\%20lab\%20-\%20HW\%20 calculator.xls) was applied to confirm the independent segregation of the alleles. Chi-square test, ANOVA and ANCOVA for adjustments (for sex, age and untreated plasma levels) were used for statistical analysis. All tests were two tailed and the significance level $\mathrm{P}<0.05$ was considered to be significant at primary analysis. 
Further, Bonferroni correction for multiple testing (nine variants were analyzed) was applied. The changes of plasma lipids were compared between subjects with different genotypes for individual polymorphisms. If there were less than $5 \%$ of the carriers of one genotype, these individuals were pooled with heterozygotes and analyzed together.

\section{Results}

\section{Basic characteristics}

There was a significant decrease in total cholesterol $\quad(7.00 \pm 1.53 \rightarrow 5.15 \pm 1.17 \mathrm{mmol} / \mathrm{l}, \quad \mathrm{P}<0.0001)$ and triglycerides $(2.03 \pm 1.01 \rightarrow 1.65 \pm 1.23 \mathrm{mmol} / \mathrm{l}$, $\mathrm{P}<0.0001$ ) as a response on statin treatment (Table 1). Plasma levels of HDL cholesterol did not change significantly $(1.43 \pm 0.48 \rightarrow 1.41 \pm 0.40 \mathrm{mmol} / \mathrm{l}, \mathrm{P}=0.08)$.

The call rates for the individual polymorphisms varied between $100 \%$ for the rs 1264264 within the HMGCoA reductase gene in patients and $93.6 \%$ for the rs 4420638 within the APOE/C1/C4 gene cluster in patients. Rs599838 variant was not detected within the 284 patients and, thus, was not genotyped in the entire groups of patient and controls.

In the analyzed groups, the genotype frequencies of individual polymorphisms were similar to the so far published frequencies in other Caucasian populations. Hardy-Weinberg test confirmed the independent segregation of individual alleles with two exceptions $(\mathrm{P}<0.0005$ for the rs16996148 in controls and $\mathrm{P}<0.01$ for the rs11206510 in patients). These differences could likely be explained as the groups do not represent general population samples, but preselected population subgroups. No gender differences in genotype frequencies were observed either in the patients or in controls (data not shown in details).

\section{Genotype differences between the analyzed groups}

The detected genotype frequencies were significantly different between the patients and controls in most of the analyzed variants (Table 3). The largest differences $(\mathrm{P}<0.0001)$ were observed for the rs646776 variant within the CELSR2 gene cluster and rs6511720 variant within the LDL receptor gene. Also other variants (with two exceptions of rs515135 and rs6235) differed between the analysed groups and, thus, certain role of these SNPs in determination of plasma lipid levels can be expected.
Associations between the SNPS and statin treatment efficacy

The carriers of minor rs $4420638 \mathrm{G}$ allele within the $\mathrm{APOE} / \mathrm{C} 1 / \mathrm{C} 3$ cluster had significantly lower response to statin treatment compared to common homozygotes if HDL cholesterol was analyzed $(\Delta+12.5 \%$ vs. $\Delta+6.1 \%$, $\mathrm{P}=0.007$ adjusted for age, sex and untreated TG levels; $\mathrm{P}=0.065$ after adjustment for multiple testing). Similar difference was obtained for plasma TG levels. However, in this case the difference was below the significance threshold after correction for multiple testing (Table 4). This variant did impact on-treatment total cholesterol levels.

For any of the other variants analyzed, we did not find a significant association between the genetic polymorphism and changes of plasma lipid levels induced by statin therapy (decrease of total cholesterol or triglycerides; increase of HDL-cholesterol) (data not shown in details).

\section{Discussion}

In a large group of adult dyslipidemic patients of Slavonic Caucasian descent we have extended our previous report (Hubáček et al. 2012) focused on analysis of the genetic determination of statin treatment efficacy. In this extended group of patient, we did not confirm our previous finding suggesting a significant effect of the SNP within the CELSR2/PSRC1/SORT1 gene cluster on statin treatment efficacy. No significant effect of the variants within genes/gene clusters for CILP2/PBX4, PCSK9, HMGCoA reductase, $L D L$ receptor or $A P O B$ on statin mediated lipid decrease was observed. At first time, we have detected a possible effect of the rs4420638 SNP within the $A P O E / C 1 / C 3$ gene cluster on statin induced changes of plasma triglycerides and HDL cholesterol. Presence of the minor allele was associated with profitable changes of TG levels and HDL-C. However, the major statin targets, total and LDL-cholesterol concentrations, decreased independently of this variant.

The detected effect of this SNP on plasma lipid changes after statin treatment is of potential interest, especially because major genetic determinants of statin treatment efficacy detected so far are two SNPs located within the same gene cluster, namely in the $A P O E$ gene (Hubacek and Vrablik 2011). APOE4 allele (rs429358) of the same gene seems to be the most powerful genetic risk factor for cardiovascular disease development (Angelopoulos and Lowndres 2010, Poledne et al. 2010). 
Table 3. Genotype distributions within the analyzed groups.

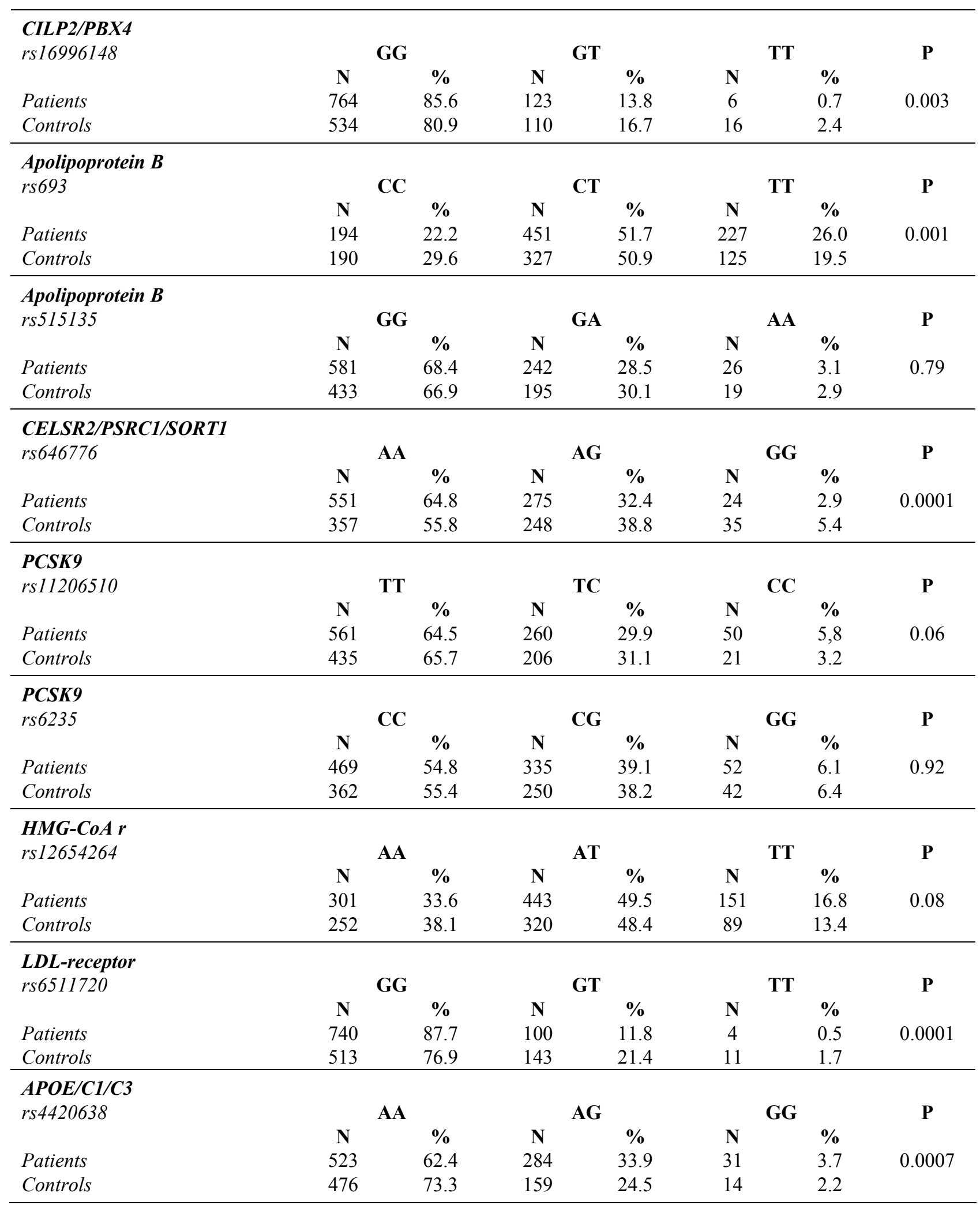

Carriers of this $A P O E 4$ allele tend to have higher, while persons carrying the $A P O E 2$ allele lower total cholesterol levels if compared to APOE3E3 homozygotes. This association is partially influenced by sex, diet or physical activity (reviewed by Hayman 2000) but has been consistently described in all populations analyzed so far.

However, there are some points which need to be taken into account. First, after correction for multiple 
Table 4. Changes of lipid parameters according to individual genotypes (expressed as percentage of the baseline value).

\begin{tabular}{|c|c|c|c|c|c|}
\hline APOE/C1/C4 & $+\mathbf{G}$ & $\mathbf{A A}$ & $+\mathbf{G}$ & $\mathbf{A A}$ & \\
\hline$r s 4420638$ & \multicolumn{2}{|c|}{ Males } & \multicolumn{2}{|c|}{ Females } & $\mathrm{P}^{*}$ \\
\hline$\Delta T-C$ & $19.4 \pm 18.0$ & $24.5 \pm 10.9$ & $27.8 \pm 10.8$ & $27.6 \pm 11.6$ & 0.14 \\
\hline$\Delta T G$ & $20.3 \pm 30.6$ & $12.5 \pm 35.1$ & $24.1 \pm 23.3$ & $13.4 \pm 31.1$ & 0.01 \\
\hline$\triangle H D L-C$ & $20.0 \pm 29.6$ & $11.2 \pm 27.0$ & $4.9 \pm 28.1$ & $4.5 \pm 20.1$ & 0.007 \\
\hline
\end{tabular}

* uncorrected $\mathrm{P}$ values, adjusted for sex, age and baseline plasma lipid levels. After Bonferroni correction $\Delta$ for HDL-C are not significant at $\mathrm{P}=0.063$.

testing, the difference did not reach the arbitrary significance level and thus the effect needs to be confirmed in second independent population. Second, primary statin targets, total and LDL-cholesterol remained completely unaffected by this SNP. Finally, despite the statistical significance $(\mathrm{P}=0.007$, but 0.06 after correction for multiple testing), the biological significance in the HDL-cholesterol change is speculative. The achieved difference between the genotypes was less than $\sim 10 \%$, what represents about $0.12 \mathrm{mmol} / \mathrm{l}$.

With two exceptions (PCSK9 and $A P O B$ regions), we have detected differences in genotype frequencies between analyzed groups of patients and controls. This confirms that most of the analyzed variants are important determinants of plasma lipid levels not in West European populations only, but also in the central European Slavonic population.

The genotype frequencies of two variants within the two genes ( $A P O B$ and $P C S K 9$ ) were almost identical among the dyslipidemic patients and normolipidemic controls. This underlines the importance of the confirmatory studies and points to the possibility, that even genome wide analyses (GWAs) could detect a variant without any general effects on plasma lipids and even the chance of the false positive results could not be excluded. This is not the first time that GWAs results were not confirmed in population(s) of different origin. For example, we were not able to confirm the association between the powerful genetic determinants of plasma TG levels (Kooner et al. 2008) within the MLXIPL gene. In a study with sufficient power (Vrablik et al. 2008) this variant was neither associated with plasma TG levels in the population, nor were the genotype frequencies different between the individuals with low and high plasma TG levels.

One of the explanations may be the different genetic or, more likely, different environmental and lifestyle background between the west European/German and central European/Slavonic populations. Some variants likely effect plasma lipid levels regardless on dietary habits or physical activity, effects of others probably need to be triggered by unfavorable lifestyle.

Loci we have studied include not only the well known genes with a clear link to plasma lipid values as $A P O B, A P O E, L D L$ receptor, PCSK9 and HMGCOA reductase, but also the gene clusters with rather unclear mechanisms affecting plasma lipid concentrations - the variants being located within the intergenic regions of the CELSR2 (Waterworth et al. 2010) and CILP2 (Seki et al. 2005) gene clusters. At time of their discovery, the gene products of these clusters had no known association with plasma lipid metabolism, but later, thanks to the GWAs results, SORT1, a member of the CELSR2 gene cluster, was recognized to be an intracellular receptor interacting with $\mathrm{APOB}$ at the apparatus of Golgi facilitating the hepatic transport of APOB containing lipoproteins (Kjolby et al. 2010).

Variation of the new gene loci contributing to the development of dyslipidemia (Kathiresan et al. 2008, Sandhu et al. 2008, Aulchenko et al. 2009), did not influence therapeutic effect of statins and their contribution to interindividual variability of the final impact of statin therapy on lipoprotein concentrations seems to be neglectable.

The reason for the observed lack of association could be the fact, that these genes do not alter the pathway(s) involved in the metabolism or transport of statins. In general, these pathways are supposed to be more likely affecting statin treatment efficacy (or there is a greater chance to detect such an effect), as they are less prone to environmental modifications. Variations we have studied potentially impact pathways that involve transport proteins or enzymes directly linked to processing of different lipoprotein subpopulations (mostly LDL and TG-rich particles) and not to the 
metabolism or transport of statins.

Another possibility might be only modest modifying effect, which could not be recognized due to the relatively small sample size and patient heterogeneity. We want to underline, that the observed differences between the genotypes were mostly minimal. Thus, it is unlikely that even a substantially increased sample size would enable identification of any modifying effects of clinical significance.

The increasing popularity of genome wide association studies (Rosenberg et al. 2010) has also its pitfalls. Most importantly, there is a substantial lack of the replication studies (Munafò 2009) performed (or published) and thus some publication bias needs to be expected and the real effect in different populations could be over- or under- estimated. Further, also detailed analyses of interethnic or even international differences or possible gene-gene or gene-environment interactions have never been analyzed in these studies.

It is of outstanding interest to understand the genetic puzzle of the drug efficacy, as we do not have any other kind of tests to predict the effects of pharmacotherapy and prediction of the individual efficacy of a drug can be done only by methods of genetic analysis. Such test would have a potential to detect the high- and hypo- responders and, moreover, identification of those at high risk of side effects. The genetic analyses could allow us to select the most effective and, more importantly, safer treatment alternative for an individual patient. The economical and health benefits of this approach are evident, but we are at the very beginning to understand the genetic determination of statin treatment efficacy (Ordovas and Mooser 2002, Mangravite et al. 2010).

The impact of genetic polymorphisms on statin treatment efficacy has been analyzed in several clinical trials. So far, variants in more than 30 different genes have been examined (Mangravite and Krauss 2007, Maggo et al. 2011) but the results were not replicated in larger patient groups and also the magnitude of impact on statin efficacy was small. Interestingly only the impact of the $A P O E$ gene on statin treatment efficacy was analyzed in more studies (reviewed by Hubacek and Vrablik 2011) and despite the results are far from being consistent, $A P O E 4$ allele is associated with poorer response to statin treatment. Other genes analyzed include for example apolipoprotein A5 (Hubacek et al. 2009) or cholesterol 7-alpha hydroxylase (Kajinami et al. 2005) The expanding knowledge in this field is quickly growing, but, so far, it is not sufficient to be used in clinical practice. Only comprehensive interdisciplinary biomedical research (Berger 2011) in large populations focused on impact of gene-gene-environment interactions will enable to broaden our understanding of the determination of statin treatment efficacy.

Our pilot study was focused on the analysis of the new role of gene loci identified through genome wide association studies in pharmacogenetic of statin treatment. We have detected a potential of the rs 4420638 variant within the $A P O E / C 1 / C 3$ gene cluster (but not within CILP2/PBX4, PCSK9, LDL receptor, HMGCoA reductase, CELSR2/PSRC1/SORT1 and APOB gene loci) to significantly impact on statin treatment efficacy. If this variant could be of clinical importance needs to be analyzed in a large clinical trial.

\section{Conflict of Interest}

There is no conflict of interest.

\section{Acknowledgements}

The study was supported by project No. NS 10579-3 from the IGA, MH, Czech Republic.

\section{Abbreviations}

APO, apolipoprotein; CELSR2/PSRC1/SORT1, cadherin egf lag seven-pass g-type receptor $2 /$ proline/serine-rich coiled-coil protein 1/sortilin1; CILP2/PBX4, cartilage intermediate layer protein 2/ pre-b-cell leukemia transcription factor 4; GWA, genome wide association; HMGCoA, 3-hydroxy-3-methylglutaryl coenzyme A; MONICA, MONItoring of CArdiovascular disease; PCSK9, proprotein convertase, subtilisin/kexin-type, 9; SNP, single nucleotide polymorphism.

\section{References}

ANGELOPOULOS TJ, LOWNDES J: ApoE genotype: impact on health, fitness and nutrition. World Rev Nutr Diet 98: 77-93, 2008. 
AULCHENKO YS, RIPATTI S, LINDQVIST I, BOOMSMA D, HEID IM, PRAMSTALLER PP, PENNINX BW, JANSSENS AC, WILSON JF, SPECTOR T, MARTIN NG, PEDERSEN NL, KYVIK KO, KAPRIO J, HOFMAN A, FREIMER NB, JARVELIN MR, GYLLENSTEN U, CAMPBELL H, RUDAN I, JOHANSSON A, MARRONI F, HAYWARD C, VITART V, JONASSON I, PATTARO C, WRIGHT A, HASTIE N, PICHLER I, HICKS AA, FALCHI M, WILLEMSEN G, HOTTENGA JJ, DE GEUS EJ, MONTGOMERY GW, WHITFIELD J, MAGNUSSON P, SAHARINEN J, PEROLA M, SILANDER K, ISAACS A, SIJBRANDS EJ, UITTERLINDEN AG, WITTEMAN JC, OOSTRA BA, ELLIOTT P, RUOKONEN A, SABATTI C, GIEGER C, MEITINGER T, KRONENBERG F, DÖRING A, WICHMANN HE, SMIT JH, MCCARTHY MI, VAN DUIJN CM, PELTONEN L; ENGAGE CONSORTIUM: Loci influencing lipid levels and coronary heart disease risk in 16 European population cohorts. Nat Genet 41: 47-55, 2009.

BERGER J: The age of biomedicine: current trends in traditional subjects. J Appl Biomed 9: 57-61, 2011.

DAY IN, HUMPHRIES SE: Electrophoresis for genotyping: microtiter array diagonal gel electrophoresis on horizontal polyacrylamide gels, hydrolink, or agarose. Anal Biochem 222: 389-395, 1994.

HACHEM SB, MOORADIAN AD: Familial dyslipidaemias: an overview of genetics, pathophysiology and management. Drugs 66: 1949-1969, 2006.

HAYMAN LL: Abnormal blood lipids: is it environment or is it genes? J Cardiovasc Nurs 14: 39-49, 2000.

HUBACEK JA, VRABLIK M: Effect of apolipoprotein E polymorphism on statin-induced decreases in plasma lipids and cardiovascular events. Drug Metabol Drug Interact 26: 13-20, 2011.

HUBACEK JA, ADAMKOVA V, PRUSIKOVA M, SNEJDRLOVA M, HIRSCHFELDOVA K, LANSKA V, CESKA R, VRABLIK M: Impact of apolipoprotein A5 variants on statin treatment efficacy. Pharmacogenomics 10: 945-950, 2009.

HUBÁČEK JA, ADÁMKOVÁ V, LÁNSKÁ V, DLOUHÁ D, RYNEKROVÁ J, ZLATOHLÁVEK L, PRUSÍKOVÁ M, ČEŠKA R, VRABLÍK M: Variant within CELSR2/PSRC1/SORT1, but not within CILP2/PBX4, PCSK9 and $A P O B$ genes, has a potential to influence statin treatment efficacy. $J$ Appl Biomed 10: 19-28, 2012.

KAJINAMI K, BROUSSEAU DE, ORDOVAS JM, SCHAEFER EJ: A promoter polymorphism in cholesterol 7alphahydroxylase interacts with apolipoprotein E genotype in the LDL-lowering response to atorvastatin. Atherosclerosis 180: 407-415, 2005.

KATHIRESAN S, MELANDER O, GUIDUCCI C, SURTI A, BURTT NP, RIEDER MJ, COOPER GM, ROOS C, VOIGHT BF, HAVULINNA AS, WAHLSTRAND B, HEDNER T, CORELLA D, TAI ES, ORDOVAS JM, BERGLUND G, VARTIAINEN E, JOUSILAHTI P, HEDBLAD B, TASKINEN MR, NEWTON-CHEH C, SALOMAA V, PELTONEN L, GROOP L, ALTSHULER DM, ORHO-MELANDER M: Six new loci associated with blood low-density lipoprotein cholesterol, high-density lipoprotein cholesterol or triglycerides in humans. Nat Genet 40: 189-197, 2008. Erratum in: Nat Genet 40: 1348, 2008.

KJOLBY M, ANDERSEN OM, BREIDERHOFF T, FJORBACK AW, PEDERSEN KM, MADSEN P, JANSEN P, HEEREN J, WILLNOW TE, NYKJAER A: Sort1, encoded by the cardiovascular risk locus 1p13.3, is a regulator of hepatic lipoprotein export. Cell Metab 12: 213-223, 2010.

KOONER JS, CHAMBERS JC, AGUILAR-SALINAS CA, HINDS DA, HYDE CL, WARNES GR, GÓMEZ PÉREZ FJ, FRAZER KA, ELLIOTT P, SCOTT J, MILOS PM, COX DR, THOMPSON JF: Genome-wide scan identifies variation in MLXIPL associated with plasma triglycerides. Nat Genet 40: 149-151, 2008.

MAGGO SD, KENNEDY MA, CLARK DW: Clinical implications of pharmacogenetic variation on the effects of statins. Drug Saf 34: 1-19, 2011.

MANGRAVITE LM, KRAUSS RM: Pharmacogenetics of statin response. Curr Opin Lipidol 18: 409-419, 2007.

MANGRAVITE LM, MEDINA MW, CUI J, PRESSMAN S, SMITH JD, RIEDER MJ, GUO X, NICKERSON DA, ROTTER JI, KRAUSS RM: Combined influence of LDL and HMGCR sequence variation on lipid-lowering response to simvastatin. Arterioscler Thromb Vasc Biol 30: 1485-1492, 2010.

MILLER SA, DYKES DD, POLESKY HF: A simple salting out procedure for DNA extraction from human nucleated cells. Nucleic Acid Res 16: 1215, 1988.

MUNAFÒ MR: Reliability and replicability of genetic association studies. Addiction 104: 1439-1440, 2009.

ORDOVAS JM, MOOSER V: The APOE locus and the pharmacogenetics of the lipid response. Curr Opin Lipidol 13: 113-117, 2002. 
PITHA J, BOBKOVÁ D, KOVÁŘ J, HAVLÍČKOVÁ J, POLEDNE R: Antiatherogenic effect of simvastatin is not due to decrease of LDL cholesterol in ovariectomized golden Syrian hamster. Physiol Res 59: 401-406, 2010.

POLEDNE R, HUBÁČEK JA, STANĚK V, ASCHERMANN M, MATOUŠKOVÁ J, VESELKA J, WIDIMSKÝ P, CÍFKOVÁ R, LÁNSKÁ V, PIŤHA J: Why we are not able to find the coronary heart disease gene - apoE as an example. Folia Biol (Praha) 56: 218-222, 2010.

ROSENBERG NA, HUANG L, JEWETT EM, SZPIECH ZA, JANKOVIC I, BOEHNKE M: Genome-wide association studies in diverse populations. Nat Rev Genet 11: 356-366, 2010.

SADOWITZ B, MAIER KG, GATHAN V: Basic science review: Statin therapy - Part I: The pleiotropic effects of statins in cardiovascular dinase. Vasc Endovascular Surg 44: 241-251, 2010.

SANDHU MS, WATERWORTH DM, DEBENHAM SL, WHEELER E, PAPADAKIS K, ZHAO JH, SONG K, YUAN X, JOHNSON T, ASHFORD S, INOUYE M, LUBEN R, SIMS M, HADLEY D, MCARDLE W, BARTER P, KESÄNIEMI YA, MAHLEY RW, MCPHERSON R, GRUNDY SM; WELLCOME TRUST CASE CONTROL CONSORTIUM, BINGHAM SA, KHAW KT, LOOS RJ, WAEBER G, BARROSO I, STRACHAN DP, DELOUKAS P, VOLLENWEIDER P, WAREHAM NJ, MOOSER V: LDL-cholesterol concentrations: a genome-wide association study. Lancet 371: 483-491, 2008.

SEKI S, KAWAGUCHI Y, CHIBA K, MIKAMI Y, KIZAWA H, OYA T, MIO F, MORI M, MIYAMOTO Y, MASUDA I, TSUNODA T, KAMATA M, KUBO T, TOYAMA Y, KIMURA T, NAKAMURA Y, IKEGAWA S: A functional SNP in CILP, encoding the cartilage intermediate layer protein, is associated with susceptibility tolumbar disc disease. Nat Genet 37: 607-612, 2005.

SEVER PS, DAHLOF B, POULTER NR, WEDEL H, BEEVERS G, CAULFIELD M, COLLINS R, KJELDSEN SE, KRISTINSSON A, MCINNES GT, MEHLSEN J, NIEMINEN M, O'BRIEN E, OSTERGREN J; ASCOT INVESTIGATORS: Prevention of coronary and stroke events with atorvastatin in hypertensive patients who have average or lower-than-average cholesterol concentrations, in the Anglo-Scandinavian Cardiac Outcomes Trial-Lipid Lowering Arm (ASCOT-LLA): a multicentre randomised controlled trial. Lancet 361: 1149-1158, 2003.

THUNSDALL-PEDOE H, KUULASMAA K, TOLONEN H, DAVIDSON M, MENDIS S: MONICA monograph and multimedia sourcebook. H THUNSDAL-PEDOE (ed), World Health Organisation, Geneva, 2003.

VRABLIK M, CESKA R, ADAMKOVA V, PEASEY A, PIKHART H, KUBINOVA R, MARMOT M, BOBAK M, HUBACEK JA: MLXIPL variant in individuals with low and high triglyceridemia in white population in Central Europe. Hum Genet 124: 553-555, 2008.

WANG K, LI M, HAKONARSON H: Analysing biological pathways in genome-wide association studies. Nat Rev Genet 11: 843-854, 2010.

WATERWORTH DM, RICKETTS SL, SONG K, CHEN L, ZHAO JH, RIPATTI S, AULCHENKO YS, ZHANG W, YUAN X, LIM N, LUAN J, ASHFORD S, WHEELER E, YOUNG EH, HADLEY D, THOMPSON JR, BRAUND PS, JOHNSON T, STRUCHALIN M, SURAKKA I, LUBEN R, KHAW KT, RODWELL SA, LOOS RJ, BOEKHOLDT SM, INOUYE M, DELOUKAS P, ELLIOTT P, SCHLESSINGER D, SANNA S, SCUTERI A, JACKSON A, MOHLKE KL, TUOMILEHTO J, ROBERTS R, STEWART A, KESÄNIEMI YA, MAHLEY RW, GRUNDY SM; WELLCOME TRUST CASE CONTROL CONSORTIUM, MCARDLE W, CARDON L, WAEBER G, VOLLENWEIDER P, CHAMBERS JC, BOEHNKE M, ABECASIS GR, SALOMAA V, JÄRVELIN MR, RUOKONEN A, BARROSO I, EPSTEIN SE, HAKONARSON HH, RADER DJ, REILLY MP, WITTEMAN JC, HALL AS, SAMANI NJ, STRACHAN DP, BARTER P, VAN DUIJN CM, KOONER JS, PELTONEN L, WAREHAM NJ, MCPHERSON R, MOOSER V, SANDHU MS: Genetic variants influencing circulating lipid levels and risk of coronary artery disease. Arterioscler Thromb Vasc Biol 30: 2264-2276, 2010. 